\title{
$\begin{array}{llllllll}\mathbf{R} & \mathbf{E} & \mathbf{C} & \mathbf{E} & \mathbf{N} & \mathbf{Z} & \mathbf{J} & \mathbf{E}\end{array}$
}

Prawo Kanoniczne

$58(2015) \mathrm{nr} 4$

\section{P. Skonieczny, La compartecipazione nel delitto canonico: alla ricerca del concetto teoretico, Roma 2015, ss. 564.}

Przedmiotem analiz przeprowadzonych przez P. Skoniecznego jest instytucja współudziału w przestępstwie kanonicznym. Jak sam Autor zaznacza instytucja ta, przy obecnym stanie wiedzy w odniesieniu do Kodeksu Prawa Kanonicznego 1983 r., została opracowana przez C. Papale w rozprawie doktorskiej. Nieliczne ślady można znaleźć również w kilku artykułach, które traktują o niej bezpośrednio lub przy okazji omawiania innych zagadnień z kanonicznego prawa karnego. Na polskim rynku wydawniczym ukazała się równolegle do pracy P. Skoniecznego pozycja o podobnie brzmiącym tytule (D. Borek, Concursus in delicto), do której Autor nie mógł sięgnąć ze względu na równoczesny termin jej publikacji. Słusznie zauważa, że w jurysprudencji rotalnej i Sygnatury Apostolskiej nie spotyka się wyjaśnień tejże instytucji. Opracowania dotyczące poprzedniego KPK traktowały o instytucji współudziału w przestępstwie z punktu widzenia historyczno-egzegetycznego. Autor sięga do nich w swoim opracowaniu. Zaznacza jednak, że to co zostało już opracowane nie będzie stanowiło przedmiotu jego badań, aczkolwiek z historycznego punktu widzenia domaga się dopowiedzenia ze względu na obowiązujący Kodeks. Dokonuje zatem także i tych analiz, ale nie są one motywem wiodącym. Służą one do przedstawienia tego, co jest istotą opracowania. Jest nią ukazanie instytucji współudziału w przestępstwie pod kątem jej koncepcji teoretycznej. Zamierzenia P. Skoniecznego należy uznać za wartościowe i rzeczywiście prekursorskie gdyż szeroko dyskutowana kwestia współudziału w przestępstwie (zwłaszcza na gruncie stosowania prawa) nie znalazła dotychczas silnej podbudowy teoretyczno-prawnej. Rozważania Autora nie mają jedynie na celu wyjaśnień teoretyczno-prawnych. Opracowanie teoretycznego modelu współudziału w przestępstwie służy pomocą w interpretacji obowiązujących przepisów, ocenie słuszności i prawidłowości istniejących sformułowań normatywnych, a także ewentualnym przyszłym rozwiązaniom normatywnym. 
Opracowanie P. Skoniecznego wychodzi naprzeciw istniejącym brakom. Należy uznać je za nowatorskie i jak dotychczas jedyne.

Recenzowana rozprawa składa się z trzech części, z których każda podzielona została na 3 rozdziały. Poprzedza je Wykaz skrótów i Wstęp, a zamykają Końcowe konkluzje. Ponadto 130 stron zajmują: Aneksy, Bibliografia, Streszczenie w języku angielskim i Spis treści.

Przedstawiona przez Autora wewnętrzna struktura rozprawy, a zwłaszcza proporcje poszczególnych rozdziałów, znajduje się nie tylko w granicach dopuszczalnej swobody autorskiej, lecz stanowi czytelny i logiczny układ. Każdy z dziewięciu rozdziałów zakończony jest Podsumowaniem.

Część I opracowania została poświęcona wyjaśnieniu podstawowych kwestii, w oparciu o które Autor będzie prowadził dalsze rozważania. I tak w r. I została przedstawiona teologiczna, filozoficzna i teoretyczno-prawna ratio legis kan. 1329. W r. II zostały przedstawione teorie dotyczące wspóludziału w przestępstwie z perspektywy historycznej i teoretyczno-prawnej (model: dualistyczny, monistyczny, mieszany). Omówienie w r. III procesu ustawodawczego kanonów dwóch kodeksów łacińskich oraz KKKW doprowadziło Autora do wniosku, że istniejące teoretyczne koncepcje współudziału w przestępstwie nie były brane pod uwagę podczas prac legislacyjnych. Uwaga została skupiona na uproszczeniu istniejących rozwiązań prawnych. Autor jednak dostrzega, że w procesie formowania się obowiązującego prawa, z punktu widzenia interpretacji historycznej, odzwierciedla ono model dualistyczny instytucji.

Część II P. Skonieczny poświęcił rozważaniom dotyczącym odpowiedzialności karnej współuczestnika działania przestępczego. Określenie współudziału w przestępstwie omówił w oparciu o trzy rodzaje kryteriów. I tak w r. IV omawia kryteria przedmiotowe (wielość sprawców, popełnienie przestępstwa przez każdego współdziałającego, obiektywny wpływ uczestnika na dokonanie czynu zabronionego), a w r. VI elementy podmiotowe (świadomość i wola w popełnieniu czynu zabronionego jako wspólnego i własnego) oraz element teologiczny jakim jest grzech ciężki, który zaciągają współdziałający w popełnieniu przestępstwa. Pierwsze wrażenie takiego układu materiału budzi pewne wątpliwości. Dlaczego Autor nie omówił po kolei elementów podmiotowych i przedmiotowych? Wyjaśnia to jednak gruntowna lektura jego przemyśleń przedstawionych w $\mathrm{r}$. V. Wynika $\mathrm{z}$ nich, że dokonane analizy doprowadziły go do wniosku, że obecny system kanonicznego prawa karnego przyjął model monistyczny współudziału 
w przestępstwie. Według tego modelu współudział w przestępstwie wskazuje na jednolite sprawstwo. Tym samym dotychczasowy, dualistyczny model udziału w cudzym przestępstwie został wyparty. To odkrycie pozwoliło Autorowi następnie przeanalizować elementy podmiotowe współudziału w przestępstwie odnosząc je do tych, którzy w nim uczestniczą.

W Części III znajdujemy rozważania P. Skoniecznego odnoszące się do zagadnień systemu kar w przypadku współdziałania w przestępstwie kanonicznym. W r. VII zauważa on, że ustawodawca porzucił dotychczasową zasadę odpowiedzialności zróżnicowanej na korzyść zasady indywidualnej odpowiedzialności wszystkich współdziałających w przestępstwie. Zauważa, że ustawodawca kościelny nie ustrzegł się błędów legislacyjnych w stanowieniu obowiązującego prawa, zapoznając zasady prawa karnego domagające się uwzględnienia ciężaru popełnionego przestępstwa, roli współdziałających, osobistych okoliczności, tak by uniknąć niesprawiedliwości w stosowaniu kar. W r. VIII P. Skonieczny, w świetle przeprowadzonych wcześniej rozważań, poddaje krytyce normatywne rozwiązania, wskazując na niekonsekwencję ustawodawcy w stosowaniu kar latae sententiae w odniesieniu do współdziałających w przestępstwie (obecność modelu dualistycznego). Ostatni rozdział (IX) ma charakter praktyczny, gdyż dotyczy trzech kwestii szczegółowych (przestępstwo udzielenia święceń biskupich bez mandatu papieskiego, usiłowanie zawarcia małżeństwa przez duchownego lub zakonnika, aborcja).

Podsumowanie rozważań Autora nie jest jedynie spójnym przedstawieniem przemyśleń i analiz. Posiada znaczenie praktyczne, gdyż P. Skonieczny odważnie prezentuje wnioski de lege ferenda, które zamieszcza w postaci nowego brzmienia (jego zdaniem słusznego) kann. 1329 KPK i 1417 KKKW.

Cennym dodatkiem są dołączone Aneksy. Ułatwiają one zrozumienie bardzo wnikliwych przemyśleń i wyprowadzonych wniosków. Ponadto dołączone fragmenty wielu świeckich kodeksów karnych odnoszących się do kwestii współdziałania w przestępstwie pozwalają na zrozumienie wniosków Autora, stanowiąc jednocześnie normatywne oparcie dla głoszonych przez niego tez.

Recenzowana rozprawa nie budzi zastrzeżeń co do jej poziomu warsztatowego. Autor posługuje się, jak sam to określa, głównie metodą analityczną, teoretyczną i historyczną. Bardziej właściwe byłoby jednak odwołanie się do metody logiczno-językowej oraz teologicznej zamiast analitycznej, gdyż one w formie przekazu wyników badań posługują się zdaniami analitycznymi. 
W sposób właściwy z mojego punktu widzenia i uprawiania kanonistyki łączy perspektywę teologiczną kanonistyki z osiągnięciami współczesnych nauk prawnych. Dzięki wykorzystaniu ich języka sprawia, że kanonistyczne koncepcje wkraczają na wspólny obszar nauk prawnych przy zachowaniu własnej, teologicznej specyfiki.

Język opracowania jest poprawny. Autor nie pisał we własnym języku, ale tekst włoski został poddany lingwistycznej oprawie.

Wywód prowadzony przez Autora komunikatywnym, aczkolwiek skomplikowanym pod względem technicznych określeń, językiem jest klarowny i nie budzi zastrzeżeń.

Przypisy z zastosowaniem przyjętych skrótów dokonane są prawidłowo.

Bibliografia z podziałem na Źródła (kościelne, świeckie, jurysprudencja) oraz Literaturę (polska, włoska, hiszpańska, niemiecka, angielska) jest imponująca i sprawia wrażenie wykorzystania w całości istniejących w tej materii opracowań.

Znajdują się niedopatrzenia: na s. 509 znalazł się pośród Literatury tekst źródłowy (Pontificia Commissio...Codex Iuris Canonici...).

Ponadto P. Skonieczny dokonał wyboru usystematyzowania Źródeł w oparciu o kryterium chronologiczne, nie alfabetyczne. Być może uważał, że ułatwi to śledzenie historycznych dywagacji dotyczących procesu legislacyjnego. Trudno jednak czytelnikowi odnaleźć się gdy poszukuje interesującej pozycji, która pochodzi od konkretnego autora.

Przeprowadzona powyżej ocena rozprawy w punkcie wyjścia wskazała na oryginalność tematu badawczo-naukowego. Z tej racji ocenę merytoryczną rozprawy prezentuję w kilku punktach.

1) $Z$ racji tego, że opracowanie P. Skoniecznego jest pierwszym tego rodzaju w literaturze światowej należy je uznać jako nowość. Nowość ta nie dotyczy jedynie prekursorskiego opracowania tematu współdziałania w przestępstwie kanonicznym, ale nowatorskiego podejścia do określenia modelu współdziałania, który rzuca nowe światło na istniejące rozwiązania prawne oraz na wnioski de lege ferenda.

2) P. Skonieczny podjął się próby teoretycznego opracowania kanonicznej instytucji współudziału w przestępstwie. Doszedł do cennego wniosku, który dotychczas nie był dostrzeżony zarówno w jurysprudencji Stolicy Apostolskiej jak i w istniejącej literaturze w tym temacie. 
3) W zgodzie z proponowanym modelem współdziałania w przestępstwie poddał krytyce obowiązujące rozwiązania normatywne wskazując na konieczność uniknięcia jakiejkolwiek niesprawiedliwości w stosowaniu kar.

4) Cenne dla kościelnego ustawodawcy są nie tylko teoretyczne fundamenty instytucji współudziału w przestępstwie, ale również postulaty de lege ferenda.

5) Uważam jednak, że w opracowaniu naukowym powinno się unikać stwierdzeń wydaje się, że (sembra che, s. 45). Należy odważnie postawić tezę czy hipotezę lub podawać sprawdzone dane. Ponadto wybór pewnych koncepcji (Kotarbiński) w oparciu o indywidualne uznanie sugeruje, że Autor poszukuje pewnych rozwiązań, które popierałyby jego tezy, a nie takich, na których te ostatnie są oparte.

Opracowanie P. Skoniecznego La compartecipazione nel delitto canonico: alla ricerca del concetto teoretico stanowi istotny i niepodważalny wkład w rozwój prawa kanonicznego jako dyscypliny naukowej.

o. Tomasz Gałkowski CP

\section{Quaderni di Ius Missionale, I delicti riservati alla Congregazione per la Dottrina della Fede - norme, prassi, obiezioni, a cura Claudio Papale, Città del Vaticano 2014, ss. 181.}

Papież Jan Paweł II motu proprio Sacramentorum sanctitatis tutela w dniu 30 kwietnia 2001 roku promulgował Normy De gravioribus delictis traktujące o najcięższych przestępstwach zastrzeżonych dla Kongregacji Nauki Wiary. Po niespełna dziesięciu latach okazało się niezbędne wprowadzenie do dokumentu pewnych zmian i uzupełnień, dlatego też papież Benedykt XVI w dniu 21 maja 2010 roku promulgował Normy De delictis Congregationi pro Doctrina Fidei reservatis, stanowiące uzupełnienie i modyfikację norm z 2001 roku. W obydwu przywołanych powyżej dokumentach jest mowa o najcięższych przestępstwach (nie tylko w materii de sexto) zastrzeżonych dla Kongregacji Nauki Wiary wraz z podaniem sposobu postępowania w przypadku ich zaistnienia. Jak pokazuje życie, przepisy zawarte w wymienionych normach są - niestety - cały czas aktualne, szczególne w tym, 